\title{
Study on Surrounding Rock Stability Mechanism of Gob-Side Entry Retaining with Prefabricated Fracture
}

\author{
Hao Wu $\mathbb{D}^{D}$, Chuanqu Zhu $\mathbb{D}^{\text {, }}$, and Qingfeng Li $\mathbb{D}$ \\ School of Resource and Environment and Safety Engineering, Hunan University of Science and Technology, Xiangtan, \\ Hunan 411201, China \\ Correspondence should be addressed to Hao Wu; 1457121507@qq.com
}

Received 19 June 2021; Revised 21 July 2021; Accepted 4 August 2021; Published 12 August 2021

Academic Editor: Qibin Lin

Copyright $(92021$ Hao Wu et al. This is an open access article distributed under the Creative Commons Attribution License, which permits unrestricted use, distribution, and reproduction in any medium, provided the original work is properly cited.

To study the optimal layout of prefabricated roof cutting line in gob-side entry retaining with roof cutting and pressure relief, based on the engineering geological conditions of 5249 working face in Beipingdong Coal Mine of Baoyuan Mining Company, the FLAC3D numerical simulation method was used to study the surrounding rock characteristics of gob-side entry retaining under different layout conditions of prefabricated roof cutting line, and the optimal layout of prefabricated roof cutting line in gob-side entry retaining with roof cutting and pressure relief was proposed. The results show that the roadway floor has a certain degree of floor heave with the mining process under different angles. The angle between the prefabricated roof cutting line and the vertical line of the roadway has little effect on the lateral displacement of the coal body in the mining process of gob-side entry retaining. When the cutting angle is $10^{\circ}$, the stability of the surrounding rock of gob-side entry retaining is more stable than that of other angles, and the plastic range is small. The stability of the surrounding rock of the roadway is more stable than that of other angles, which is conducive to the safe mining of 5249 working faces in Beipingdong Coal Mine.

\section{Introduction}

In recent years, roof cutting and pressure relief gob-side entry retaining technology has been widely used in coal mining. This technology cuts the roof by presplitting blasting and cuts off the long cantilever beam of the roadway roof, thereby changing the stress structure of the roof strata and reducing the support resistance. Compared with the traditional coal pillar retaining technology, it effectively improves the coal recovery rate and stress concentration [1-5]. The key to the success of roof cutting and roadway retaining is to design reasonable roof cutting parameters, which is beneficial with the law of stope ground pressure and the roof is cut down smoothly. Therefore, study on gob-side entry retaining with roof cutting mainly includes the strata behavior law and presplitting key parameters of slitting [6-11].

The main research contents involved in gob-side entry retaining include the law of surrounding rock activity, the interaction relationship between surrounding rock and support, the support in roadway, reinforcement support, and roadside support [12-16]. Around these contents, some experts and scholars studied the strata behavior law of gobside entry retaining in fully mechanized top coal caving $[17,18]$, analyzed the main parameters and adaptability of gob-side entry retaining [19-21], and according to the laboratory test results, analyzed two kinds of roof breaking modes of gob-side entry retaining in fully mechanized top coal caving and their influence on surrounding rock deformation [22, 23]. These research results have certain guiding significance for the rational use of gob-side entry retaining technology in fully mechanized caving. The surrounding rock affected by mining, including the filling body for retaining roadways in the later stage, is an interactive whole. These surrounding rock bodies interact with each other after mining, causing the overall deformation of surrounding rock bodies. In this process, the main roof, direct roof, top coal, filling body, and bottom plate form a bearing structure with self-stability. There are many factors affecting the stability of the structure, such as the location of the main roof fracture, the length of the end without top coal 
caving, the original roadway support technology, the width of the filling body, the filling method, and the strength of the filling body. It is essential to study the influence law of these factors and the deformation characteristics of roadway retaining for the rational and effective use of gob-side entry retaining technology.

Zheng et al. [24] and Kong et al. [25] used a certain mine as a prototype to carry out similar simulations and industrial tests to verify the effectiveness of the strong gang and strong angle support technology in the roadway reservation. Chen [26] used the method of hydraulic fracturing the roof to relieve pressure, fracturing the basic roof of the goaf in advance, and minimized the formation of the cantilever beam structure on the basic roof of the adjacent goaf, thereby reducing and transferring the roof of the roadway along the goaf. The strength of the supporting pressure solves the problem that the roadway along the goaf is affected by the supporting pressure of the cantilever beam formed by the unbroken basic roof of the adjacent goaf. Wang et al. [27] studied the crack development mechanism and influencing factors of the cut-top unloading roadway in the thick coal seam and proposed dividing the roadway into the advanced support zone, the dynamic pressure influence zone, and the stable zone and the criterion conditions for the development of the cracks. Wu et al. [28] analyzed the geometric shape, severity, and dynamic evolution process of surrounding rock pressure, clarified the asymmetric deformation and failure mechanism of surrounding rock along the gob-side roadway in deep wells, and proposed the key technology of grading and zoning coupling support for the surrounding rock structure.

The layout of the prefabricated top-cutting line is an important part of the technology of retaining lanes along the goaf, but there are few studies on its layout. Therefore, this paper uses the FLAC3D simulation software to simulate the engineering geological conditions of the 5249 working face of the Beipingtong Coal Mine of Baoyuan Mining Company. The layout of the prefabricated roof cut-off line affects the stability of the surrounding rock along the goaf roadway, and the optimal layout of the precast roof cut-off line can also provide a reference for similar mines along the goaf roadway work.

\section{Engineering Geology}

The 5249 working face of Beipingdong Coal Mine is located in the 4th mining area, which is close to the 5447 working face in the east and the unmining area in the west. The south is close to 6246 caving area, the north is close to 54 transportation downhill, the east working face is $100 \mathrm{~m}$ long, and the west working face is $110 \mathrm{~m}$ long. The average thickness and dip angle of coal seam in 5449 air roadway of Beipingdong Coal Mine are $1.2 \mathrm{~m}$ and $29^{\circ}$, respectively. The relative gas emission is $2.69 \mathrm{~m}^{3} / \mathrm{t}$, which belongs to the low gas mine. The ground elevation of this working face is from $+185 \mathrm{~m}$ to $+310 \mathrm{~m}$, and the floor elevation of the coal seam is from $-430 \mathrm{~m}$ to $374 \mathrm{~m}$. The direct roof of No.4 coal seam is sandy mudstone with an average of $5.4 \mathrm{~m}$, and the direct bottom is sandy mudstone with an average thickness of $1.73 \mathrm{~m}$. The histogram of the roof and floor of the coal seam is shown in Figure 1.

\section{Establishment of Numerical Model}

According to the field condition characteristics of 5249 working faces in Beipingdong Coal Mine, the FLAC3D numerical simulation model is established as shown in Figure 2. The calculation model is $100 \mathrm{~m}$ long, $50 \mathrm{~m}$ tall, and $50 \mathrm{~m}$ wide, and the average thickness of the coal seam is $1.1 \mathrm{~m}$. The whole model is divided into 56547 grids and 11325 nodes. The left, right, and lower boundaries are fixed, and the upper boundary is subjected to vertical stress.

The buried depth of the coal seam is $600 \mathrm{~m}$, and the average density of the rock stratum is $2500 \mathrm{~kg} / \mathrm{m}^{3}$. Initial vertical stress applied at the top of the model $P=15 \mathrm{MPa}$. To conform the field practice as far as possible, the Mohr-Coulomb strength criterion is adopted in the calculation process [29].

$$
\begin{aligned}
f_{s} & =\sigma_{1}-\sigma_{3}+2 c \sqrt{N_{\varnothing}}, \\
N_{\varnothing} & =\frac{1+\sin \varphi}{1-\sin \varphi} .
\end{aligned}
$$

In the formula, $\sigma_{1}$ and $\sigma_{3}$ are the minimum and maximum principal stresses, respectively, and $C$ and $\varphi$ are the demonstrated cohesion and friction angle, respectively. When $f_{s}>0$, the material will undergo shear failure. The Mohr-Coulomb model can fully reflect the strength characteristics of rock. The physical and mechanical properties of rock are shown in Table 1.

\section{Analysis of Numerical Simulation Results}

4.1. Analysis of Surrounding Rock Deformation of Roadway along Goaf. To study the layout direction of prefabricated roof cutting line in gob-side entry retaining, the models of roof cutting line deflection to the roadway roof side, vertical roadway roof, and deflection to the goaf side are established, respectively. The angle between the tangent line to the goaf side and the vertical line of the roadway roof is positive, and the angle to the roadway side is negative. As shown in Figure 3, a monitoring point is arranged at the roof and floor of the roadway, the filling wall side, and the coal side, and the deformation and displacement values of all monitoring points are recorded every $2 \mathrm{~m}$ excavation.

Figure 4 shows the variation of surrounding rock deformation of roadway under different layout angles of the cutting line. It can be seen from Figure 4(a) that the roof subsidence increases steadily with the mining progress under different roof cutting angles before the mining reaches $30 \mathrm{~m}$. When the vertical angle between the roof cutting line and the roadway is $-5^{\circ}$, the slope is the largest because at this time the roof cutting line is biased towards the roadway side, and the stress concentration occurring in the roadway is the closest under the conditions of $10^{\circ}$ and $15^{\circ}$. When the mining is $30-40 \mathrm{~m}$, the slope of the curve is slightly slowed down, and the slope is the most obvious when the angle of the tangent top line and the vertical line of the roadway is $10^{\circ}$ compared with other angles. When mining $40-50 \mathrm{~m}$, because the model of the entire coal seam mining is completed, the roadway roof subsidence curve shows a significant trend 


\begin{tabular}{|c|c|c|c|}
\hline Rock name & Histogram & Thickness (m) & Lithologic description \\
\hline $\begin{array}{l}\text { Fine } \\
\text { sandstone }\end{array}$ & 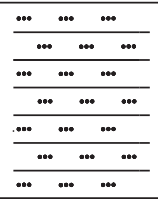 & $\frac{20-17.16}{7.68}$ & $\begin{array}{l}\text { Shallow gray-grey quartz fine sandstone, with thin sandy } \\
\text { mudstone band, siliceous cementation, dense hard wavy } \\
\text { bedding }\end{array}$ \\
\hline $\begin{array}{l}\text { Sandy } \\
\text { mudstone }\end{array}$ & 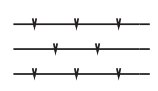 & $\frac{1.64-8.74}{3.95}$ & $\begin{array}{l}\text { Ash-deep gray sandy mudstone, containing plant } \\
\text { fossil coal line, and horizontal bedding }\end{array}$ \\
\hline $\begin{array}{l}\text { Fine } \\
\text { sandstone }\end{array}$ & $\begin{array}{lll}\cdots & \cdots & \cdots \\
\ldots & \cdots \\
\cdots & \cdots & \cdots \\
\cdots & \ldots & \cdots \\
\cdots & \ldots & \cdots \\
\end{array}$ & $\frac{0-10.12}{4.17}$ & $\begin{array}{l}\text { Light gray-grey quartz fine sandstone, thin-layer silica gel, } \\
\text { hard wavy oblique bedding }\end{array}$ \\
\hline $\begin{array}{l}\text { Sandy } \\
\text { mudstone }\end{array}$ & 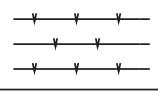 & $\frac{1.3-12.04}{3.96}$ & $\begin{array}{l}\text { Gray - black sandy mudstone, containing fossil plants and Iron } \\
\text { nodules, sometimes fine sandstones intersected by coal-line }\end{array}$ \\
\hline $\begin{array}{l}\text { Fine } \\
\text { sandstone }\end{array}$ & 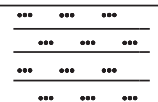 & $\frac{0.6-2.1}{1.4}$ & $\begin{array}{c}\text { Gray - white - feldspar quartz sandstone, siliceous } \\
\text { cementation, dense }\end{array}$ \\
\hline $\begin{array}{l}\text { Sandy } \\
\text { mudstone }\end{array}$ & 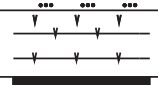 & $\frac{3.0-10.80}{5.40}$ & $\begin{array}{l}\text { Dark gray - black sandy mudstone, locally fine sandstone, } \\
\text { containing plant fossils and iron nodules }\end{array}$ \\
\hline Four coals & & $\frac{0.8-1.2}{1.1}$ & Block, semi-bright, main coal seam, local single coal seam \\
\hline $\begin{array}{l}\text { Sandy } \\
\text { mudstone }\end{array}$ & 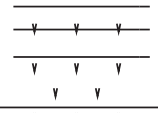 & $\frac{0.9-3.87}{2.67}$ & $\begin{array}{l}\text { Black sandy mudstone or argillaceous, thin, containing } \\
\text { fossil plant roots }\end{array}$ \\
\hline $\begin{array}{l}\text { Sandy } \\
\text { mudstone }\end{array}$ & 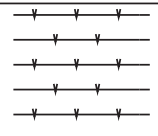 & $\frac{1.9-18.7}{7.4}$ & $\begin{array}{l}\text { Deep gray sandy mudstone, containing plant fossils } \\
\text { and iron nodules, thin sandstone }\end{array}$ \\
\hline
\end{tabular}

FIgURE 1: Comprehensive histogram of mining area 5249.

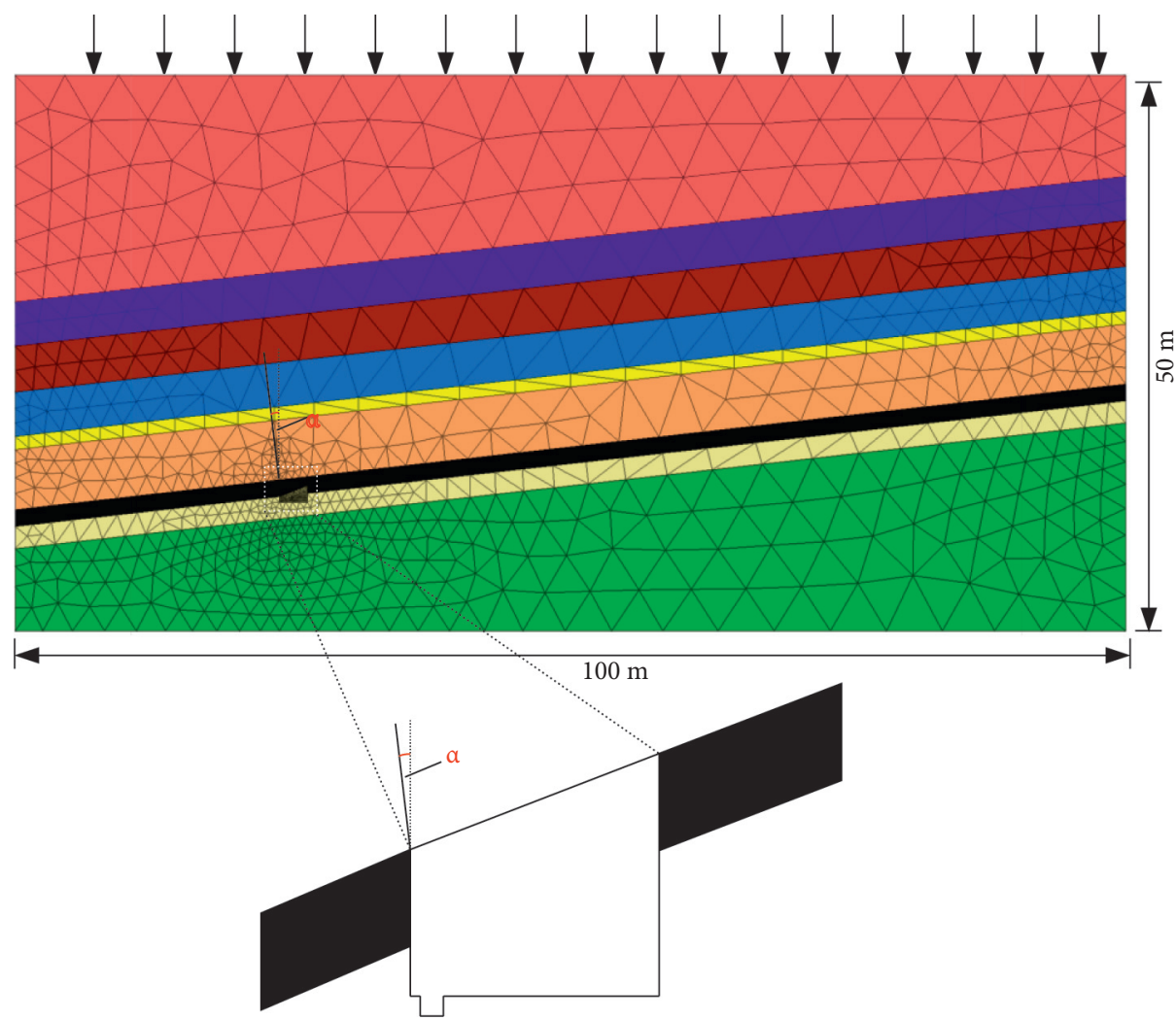

Figure 2: Numerical simulation model. 
TABle 1: Physical and mechanical properties of rock mass.

\begin{tabular}{lcccccc}
\hline $\begin{array}{l}\text { Coal seam and } \\
\text { strata }\end{array}$ & $\begin{array}{c}\text { Bulk modulus } \\
(\mathrm{GPa})\end{array}$ & $\begin{array}{c}\text { Shear modulus } \\
(\mathrm{GPa})\end{array}$ & $\begin{array}{c}\text { Tensile strength } \\
(\mathrm{MPa})\end{array}$ & $\begin{array}{c}\text { Cohesion } \\
(\mathrm{MPa})\end{array}$ & $\begin{array}{c}\text { Internal friction } \\
\text { angle }\left({ }^{\circ}\right)\end{array}$ & $\begin{array}{c}\text { Density } \\
\left(\mathrm{kg} \cdot \mathrm{m}^{-3}\right)\end{array}$ \\
\hline Sandy mudstone & 8.85 & 5.93 & 0.1 & 2.71 & 32 & 2600 \\
Four coals & 3.8 & 4.21 & 4.38 & 4.21 & 32 & 1400 \\
Fine sandstone & 2.0 & 1.3 & 0.6 & 1.6 & 34 & 2700 \\
\hline
\end{tabular}

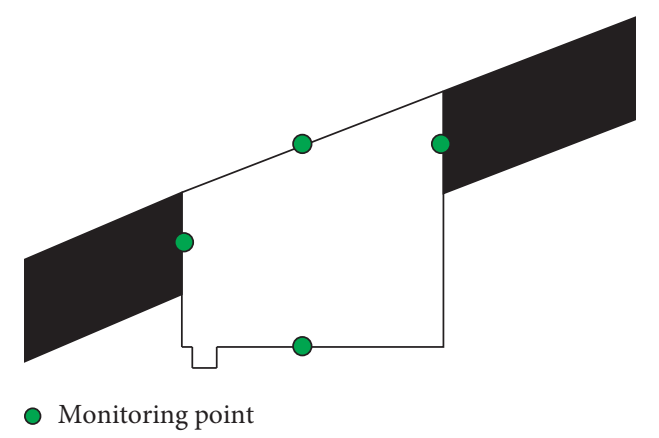

Figure 3: Layout of monitoring points.

of larger; after the completion of coal seam mining strata reach equilibrium again, the roof subsidence is maximum when the vertical angle of the roof cut line and the roadway is $-5^{\circ}$ and the roof subsidence is minimum when the angle is $10^{\circ}$.

From Figure 4(b), it can be seen that the floor of the roadway has a certain degree of floor heave with the mining process under different angles. There is a small settlement in the first $10 \mathrm{~m}$ of the mining, and then the amount of floor heave begins to increase rapidly when the excavation is $30 \mathrm{~m}$. This is because most of the roof strata are suspended after the pressure relief, which leads to the downward transfer of roof pressure. The stress release of the floor strata into the space causes the floor heave. The increased speed is the slowest under the condition of $10^{\circ}$. The increased speed further increases at the last $10 \mathrm{~m}$ of the mining and reaches a stable value. When the angle of the roof cutting line and the vertical line of the roadway is $10^{\circ}$, the floor heave is the best. In addition, the floor heave of roadway along the goaf is affected by the depth of roadway, the nature of surrounding rock, roadway size, section size, and other factors. Because the buried depth of 5249 working face and the section size of roadway in Beipingdong Coal Mine of Baoyuan Mining Company have been determined, this paper only studies the influence of prefabricated roof cutting angle on the stability of surrounding rock of roadway and takes the floor heave of floor as an important index to measure the stability of surrounding rock. According to the amount of floor heave under different roof cutting angles, floor heave will occur under various angles. The selection of roof cutting angle with relatively small amount of floor heave is helpful to the control of surrounding rock stability in the mining process and is conducive to the normal and safe mining of working face.

By cutting off the link between the gob-side entry retaining and the roof of the goaf side, the filling wall of the roadway bears the force of the whole overlying strata during the collapse of the overlying strata in the goaf. The filling wall will be squeezed to the roadway side by the vertical stress of the overlying strata, as shown in Figure 4(c). It can be seen from the figure that when the vertical angles between the prefabricated roof cutting line and the roadway are $-5^{\circ}$ and $5^{\circ}$, the displacement of the roadway filling wall is significantly greater than that of other angles. When the angle is $10^{\circ}$, the increase in the displacement curve is relatively flat compared with other angles, and the displacement is small in all angles simulated after mining.

The right side of the gob-side entry retaining model is the coal body, which is squeezed by the overlying strata due to the influence of dynamic disturbance during the mining process. As shown in Figure 4(d), the coal side moves along the $X$ positive direction during the simulation mining process. It is known from the figure that the movement is relatively small. This is because the large area of rock above the coal body is a complete rock layer, and there is a certain distance from the cutting top line, so the influence of dynamic disturbance on the coal side is small. When the excavation is $10 \mathrm{~m}-40 \mathrm{~m}$, the angle of $-5^{\circ}$ and $10^{\circ}$ is close and less than other angles. When the end of the excavation reaches the balance, the movement of all angles is close. It shows that the angle between the prefabricated roof cutting line and the vertical roadway has little effect on the lateral movement of coal in the process of gob-side entry retaining mining, but the movement of $10^{\circ}$ is the smallest.

From the above analysis, it can be seen that when the roof cutting angle is $10^{\circ}$, the connection between the roof of the gob-side entry retaining and the roof of the goaf side is well cut off, and the disturbance of the collapse of the overlying strata on the surrounding rock of the roadway is separated. The stability of the surrounding rock of the gobside entry retaining is more stable than that of other angles, which is conducive to the safe mining of the thin coal seam working face. 


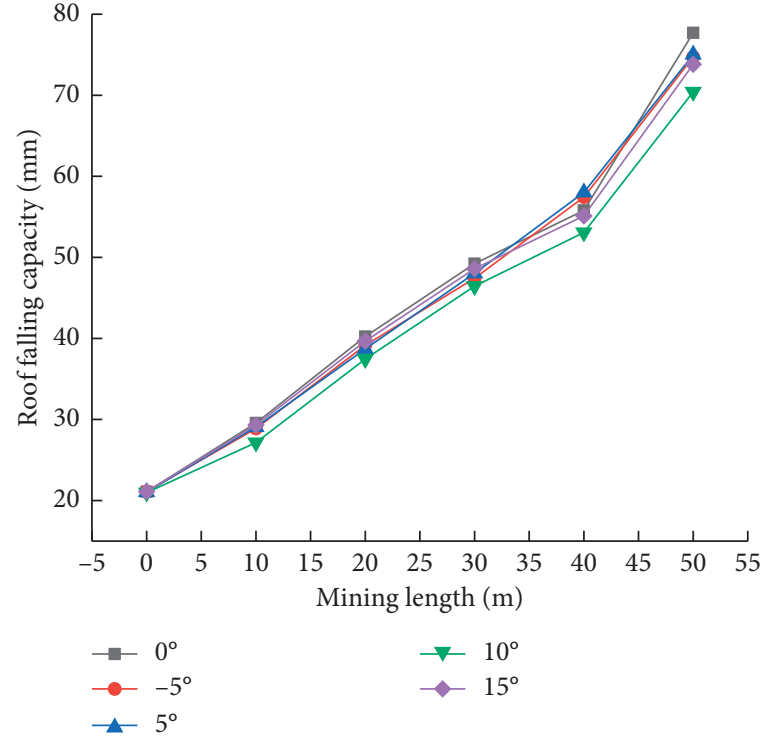

(a)

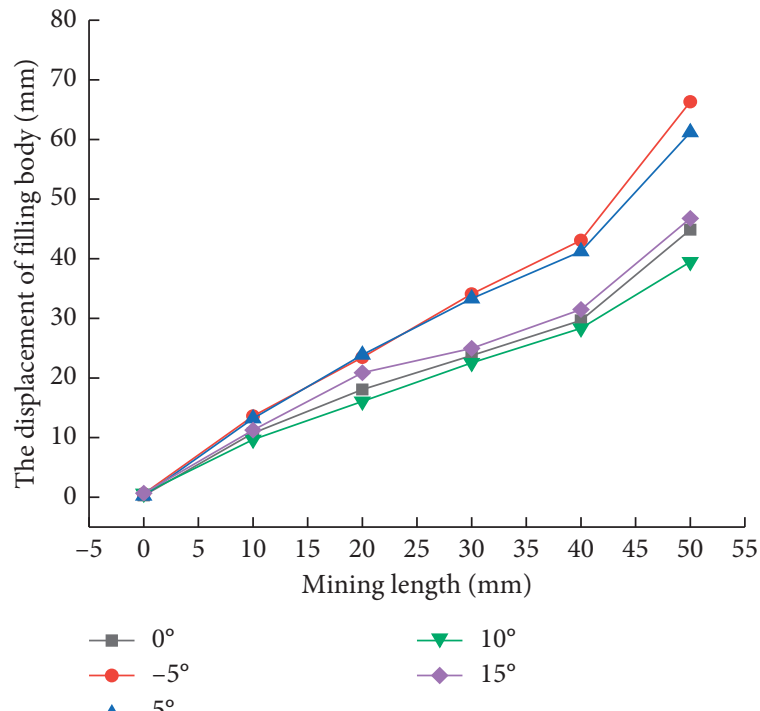

(c)

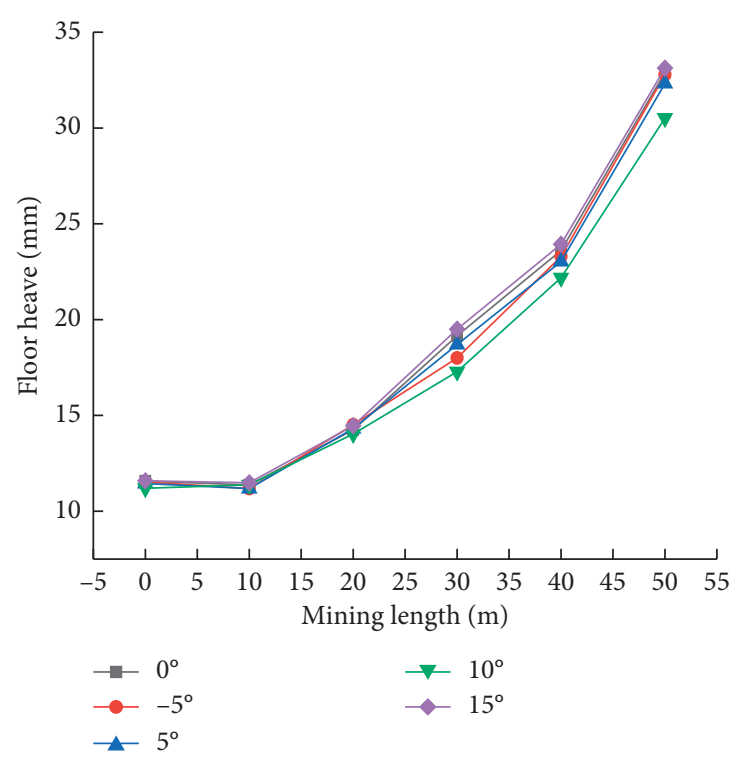

(b)

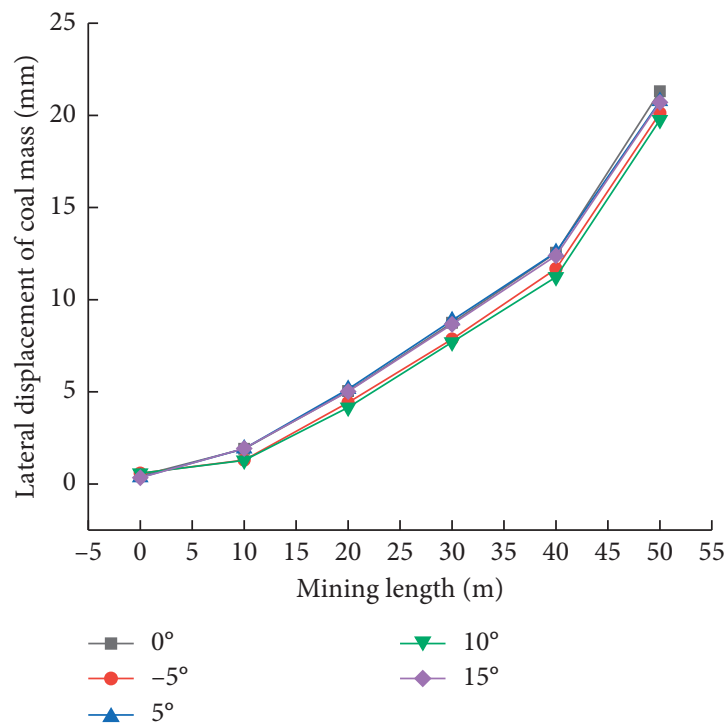

(d)

FIGURE 4: Variation of surrounding rock deformation of roadway: (a) roof subsidence curve; (b) curve of floor heave; (c) displacement of filling wall; (d) coal body convergence curve.

4.2. Analysis of Plastic Zone of Surrounding Rock of Roadway along Goaf. With the continuous advancement of the working face, the free space between the caving height range and the upper stable rock stratum will gradually increase. However, the broken rock mass does not bear the vertical pressure of the upper rock stratum, and a large area of suspended roof space and a long-term pressure relief space will be formed on the goaf side of the roadway section. At this time, the plastic failure of the surrounding rock of the roadway will occur. The analysis of the plastic zone of the surrounding rock of the gob-side entry retaining with roof cutting and pressure relief is an important basis for selecting a reasonable roof cutting angle. Plastic failure occurs in the surrounding rock of roadway retained in each mining process. With the increase in mining times, the area of plastic zone will be larger and larger. In order to select the best cutting angle, the maximum plastic zone range under different cutting angles after the mining of model coal seam is selected for comparison. As shown in Figure 5, the distribution characteristics of plastic zone of surrounding rock mass structure after gob-side entry retaining mining are completed under different layout angles of top-cutting line.

In advance of the gob-side entry retaining working face, the caving rock mass does not bear the vertical stress of the upper rock stratum, which makes the goaf side form a large area of hanging roof space. Under the pressure of the overlying rock stratum, there is a large friction and relative dislocation between the caving rock mass and the 


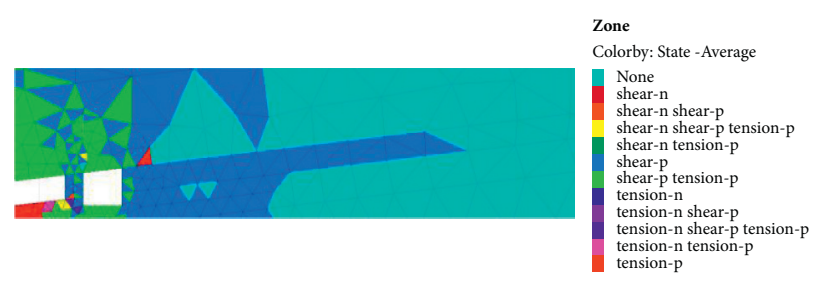

(a)

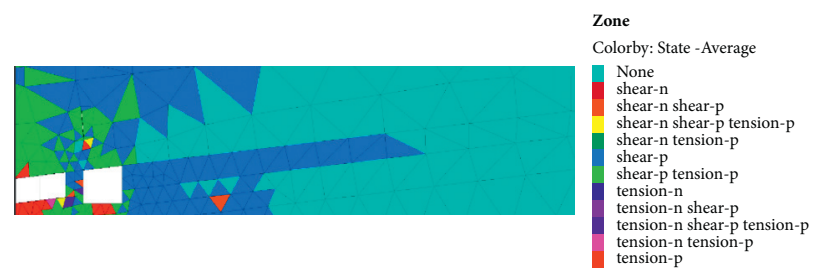

(c)

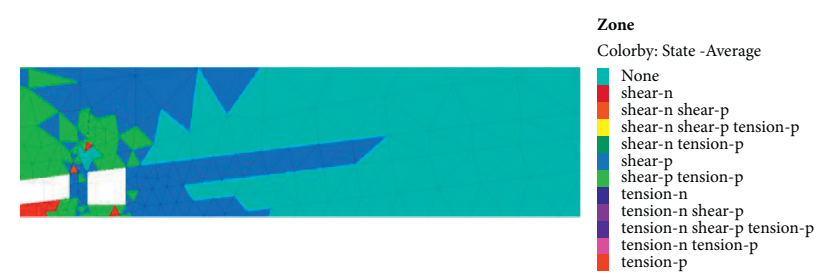

(b)

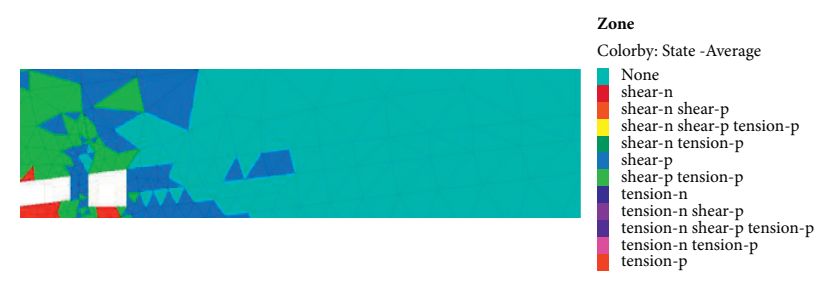

(d)

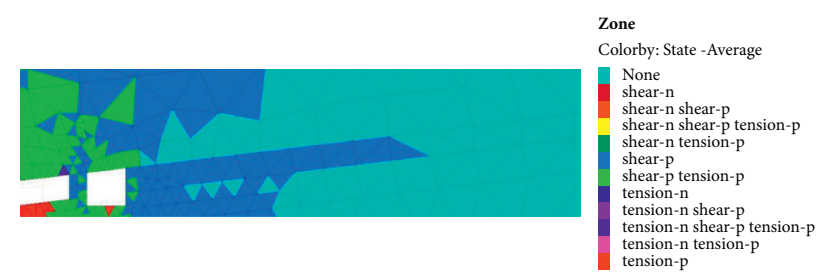

(e)

Figure 5: Distribution chart of surrounding rock plasticity under different cutting angles of prefabrication: (a) $0^{\circ}$; (b) $-5^{\circ}$; (c) $5^{\circ}$; (d) $10^{\circ}$; (e) $15^{\circ}$.

presplitting interface of the roof. Because the filling wall and the whole overlying rock stratum of the roadway roof have a large range of pure shear plastic zones, tensile failure occurs in a certain range of the roadway roof and the overlying rock stratum of the goaf. When the angle between the prefabricated roof cutting line and the roadway roof is $10^{\circ}$, the plastic failure zone of the whole model is the smallest. To obtain a layout of the prefabricated roof cutting line of the gob-side entry with better surrounding rock control, the vertical angle between the prefabricated roof cutting line and the roadway roof should be $10^{\circ}$.

\section{Conclusion}

(1) The roadway floor has a certain degree of floor heave with the mining process under different angles. The angle between the prefabricated roof cutting line and the vertical roadway has little effect on the lateral displacement of the coal body in the mining process of gob-side entry retaining. When the roof cutting angle is $10^{\circ}$, the deformation of the roadway surrounding rock is the best.

(2) The large friction and relative dislocation between the caving rock mass and the presplitting interface of the roof lead to a large range of plastic zones in the roof of the roadway and the overlying strata of the goaf, and the plastic zone is the smallest when the angle is $10^{\circ}$.

(3) When the roof cutting angle is $10^{\circ}$, the connection between the gob-side entry retaining roof and the gob-side roof is well cut off, and the disturbance of the collapse of the overlying strata on the surrounding rock of the roadway is separated. The stability of the surrounding rock of the gob-side entry retaining is more stable than that of other angles, which is conducive to the safe mining of the 5249 working face in Beipingdong Coal Mine.

\section{Data Availability}

The data used to support the findings of this study are available from the corresponding author upon request.

\section{Conflicts of Interest}

The authors declare that they have no conflicts of interest.

\section{References}

[1] N. Meng, J. Bai, Y. Chen, X. Wang, W. Wu, and B. Wu, "Stability analysis of roadside backfill body at gob-side entry retaining under combined static and dynamic loading," Engineering Failure Analysis, vol. 127, Article ID 105531, 2021.

[2] X. Yu, Z. Sun, M. Deng, and J. Xin, "Grouting technique for gob-side entry retaining in deep mines," Advances in Civil Engineering, vol. 2021, Article ID 5343937, 9 pages, 2021.

[3] Z. Xiao and K. Hongpu, "Pressure relief mechanism of directional hydraulic fracturing for gob-side entry retaining and its application," Shock and Vibration, vol. 2021, Article ID 6690654, 8 pages, 2021.

[4] T. Qin, K. Ren, C. Jiang, Y. Duan, Z. Liu, and L. Wang, "Distribution law of mining stress of the gob-side entry retaining in deep mining thin coal seam," Advances in Civil Engineering, vol. 2021, Article ID 5589948, 9 pages, 2021. 
[5] Y. Zhang, H. Xu, P. Song, X. Sun, M. He, and Z. Guo, "Stress evolution law of surrounding rock with gob-side entry retaining by roof cutting and pressure release in composite roof," Advances in Materials Science and Engineering, vol. 2020, Article ID 1961680, 15 pages, 2020.

[6] D. Kong, S. Pu, Z. Cheng, G. Wu, and Y. Liu, "Coordinated deformation mechanism of the top coal and filling body of gob-side entry retaining in a fully mechanized caving face," International Journal of Geomechanics, vol. 21, no. 4, Article ID 04021030, 2021.

[7] X. Liu, X. Hua, P. Yang, and Z. Huang, "A study of the mechanical structure of the direct roof during the whole process of non-pillar gob-side entry retaining by roof cutting," Energy Exploration \& Exploitation, vol. 38, no. 5, pp. 1706$1724,2020$.

[8] Z. Zhang, M. Deng, J. Bai, X. Yu, Q. Wu, and L. Jiang, "Strain energy evolution and conversion under triaxial unloading confining pressure tests due to gob-side entry retained," International Journal of Rock Mechanics and Mining Sciences, vol. 126, Article ID 104184, 2020.

[9] Z. Zhang, M. Deng, J. Bai, S. Yan, and X. Yu, "Stability control of gob-side entry retained under the gob with close distance coal seams," International Journal of Mining Science and Technology, vol. 31, no. 2, pp. 321-332, 2021.

[10] Z. Zhang, J. Bai, Y. Chen, and S. Yan, "An innovative approach for gob-side entry retaining in highly gassy fullymechanized longwall top-coal caving," International Journal of Rock Mechanics and Mining Sciences, vol. 80, pp. 1-11, 2015.

[11] Z. Zhang, W. Wang, S. Li et al., "An innovative approach for gob-side entry retaining with thick and hard roof: a case study," Technical Gazette, vol. 25, no. 4, pp. 1028-1036, 2018.

[12] X. Sun, Y. Liu, J. Wang, J. Li, S. Sun, and X. Cui, "Study on three-dimensional stress field of gob-side entry retaining by roof cutting without pillar under near-group coal seam mining," Processes, vol. 7, no. 9, 552 pages, 2019.

[13] C. Han, N. Zhang, J. Xue, J. Kan, and Y. Zhao, "Multiple and long-term disturbance of gob-side entry retaining by grouped roof collapse and an innovative adaptive technology," Rock Mechanics and Rock Engineering, vol. 52, no. 8, pp. 2761-2773, 2019.

[14] X. Liu, D. Fan, Y. Tan et al., "Failure evolution and instability mechanism of surrounding rock for close-distance parallel chambers with super-large section in deep coal mines," International Journal of Geomechanics, vol. 21, no. 5, Article ID 04021049, 2021.

[15] X. Liu, S. Song, Y. Tan et al., "Similar simulation study on the deformation and failure of surrounding rock of a large section chamber group under dynamic loading," International Journal of Mining Science and Technology, vol. 31, no. 3, pp. 495-505, 2021.

[16] X. Liu, D. Fan, Y. Tan et al., "New detecting method on the connecting fractured zone above the coal face and a case study," Rock Mechanics and Rock Engineering, vol. 54, no. 8, pp. 4379-4391, 2021.

[17] P. Gong, Z. Ma, J. Sun, and R. R. Zhang, "The blocking mechanism of the vertical feeding system of roadside support body material for backfilling gob-side entry retaining," $A d$ vances in Civil Engineering, vol. 2019, Article ID 6060197, 13 pages, 2019.

[18] S. Xiao-ming, L. Gan, S. Peng et al., "Application research on gob-side entry retaining methods in no. 1200 working face in Zhongxing mine," Geotechnical and Geological Engineering, vol. 37, no. 1, pp. 185-200, 2019.
[19] J. Zhang and Y. Li, "The stability of gob-side entry retaining in a high-gas-risk mine," Advances in Civil Engineering, vol. 2019, Article ID 7540749, 12 pages, 2019.

[20] X. Sun, L. Gan, Z. Chengwei et al., "Numerical investigation of gob-side entry retaining through precut overhanging hard roof to control rockburst," Advances in Civil Engineering, vol. 2018, Article ID 8685427, 10 pages, 2018.

[21] H. Luan, Y. Jiang, L. Zhou, and H. Lin, "Stability control and quick retaining technology of gob-side entry: a case study," Advances in Civil Engineering, vol. 2018, Article ID 7357320, 13 pages, 2018.

[22] H. Yang, S. Cao, S. Wang, Y. Fan, S. Wang, and X. Chen, "Adaptation assessment of gob-side entry retaining based on geological factors," Engineering Geology, vol. 209, 2016.

[23] Y. Xu, J. Chen, and J. Bai, "Control of floor heaves with steel pile in gob-side entry retaining," International Journal of Mining Science and Technology, vol. 263 pages, 2016.

[24] F. Zheng, L. Shan-Ren, B. Huang, C. Feng-Ji, and R. Peng, "Similar model test study on application of Qiang Bang Qiang Jiao in gob side entry retaining," Journal of Mining and Safety Engineering, vol. 38, no. 1, pp. 94-102, 2021.

[25] X. Kong, R. Shan, and T. Ju, "Model test study on deformation and failure mechanism of surrounding rock of coal roadway and its engineering application," Journal of Mining and Safety Engineering, vol. 34, no. 3, pp. 464-471, 2017.

[26] J. Chen, "Research on collaborative control technology of surrounding rock pressure relief support for gob side entry retaining," Coal Science and Technology, vol. 48, no. 8, pp. 44-49, 2020.

[27] J. Wang, S. Wang, J. Yang, Q. Wang, L. Ma, and M. He, "Roof failure mechanism and control technology of gob side entry retaining by roof cutting and pressure relief," Coal Science and Technology, vol. 45, no. 8, pp. 80-84, 2017.

[28] J. Wu, J. Kan, S. Xie, F. Xie, and Y. Zhao, "Research on asymmetric failure mechanism and control technology of gob side entry retaining in deep mine," Journal of Mining and Safety Engineering, vol. 34, no. 4, pp. 739-747, 2017.

[29] M. Qian, X. Miao, J. Xu, and X. Mao, Key Strata Theory of Strata Control, China University of Mining and Technology Press, Beijing, China, 2003. 